\title{
A proteção dos direitos sexuais e reprodutivos na Corte Interamericana de Direitos Humanos e a teoria dos diálogos jurisdicionais
}

\author{
Ana Paula Oliveira Ávila ${ }^{1}$ \\ Karen Cristina Correa Mello
}

\begin{abstract}
Resumo
$\mathrm{O}$ artigo analisa os direitos reprodutivos e suas implicações em face do uso de técnicas de Reprodução Assistida, como a Fertilização in vitro confrontada com o status do embrião. Empregando os métodos de revisão bibliográfica, documental e jurisprudencial, apresentam-se os aspectos biológicos e jurídicos atinentes a tais questões com um estudo de caso: a decisão da CIDH em "Artavia Murillo e outros vs. Costa Rica". A análise deste julgado, além da interpretação atribuída aos direitos reprodutivos, aprecia os diálogos jurisdicionais na sua argumentação, demonstrando como podem enriquecer o debate no cenário brasileiro, lançando luzes sobre a regulamentação desses direitos.
\end{abstract}

Palavras-chave: Direitos reprodutivos; aborto; direitos humanos; diálogos jurisdicionais

\section{Introdução}

Os centros médicos que oferecem as técnicas de reprodução assistida vêm se multiplicando em todo o mundo nos últimos anos devido à grande procura, em grande parte decorrente de uma diminuição global da fertilidade humana e também das tendências atuais de postergar-se a procriação em detrimento dos estudos e carreiras profissionais. No Brasil disponibilizam-se a Fertilização in vitro (FIV) e outras técnicas ${ }^{3}$ relacionadas ao tratamento da infertilidade ${ }^{4}$, tanto no

\footnotetext{
${ }^{1}$ Primeira colocada no curso de graduação em Ciências Jurídicas e Sociais pela Pontifícia Universidade Católica do Rio Grande do Sul (1994). Bolsista na Escola Superior do Ministério Público do RS (1995). Mestrado em Sociedade e Estado em Perspectiva de Integração pela Universidade Federal do Rio Grande do Sul (1999) e Doutorado em Direito pela UFRGS (2007). Estágio Pós-Doutoral e Master in Global Rule of Law em curso pela Universidade de Genova - Itália. Professora Titular de Direito Constitucional e Direito Econômico dos Cursos de Graduação e Mestrado - UniRitter (Porto Alegre, 1996-2017). Coordenadora do Programa de Pós-Graduação Stricto Sensu - Mestrado em Direito do UniRitter (Porto Alegre, 2014-2016). Diretora Adjunta da Escola Superior de Advocacia da OAB/RS (2013-2015). Tem experiência na área de direito público, com ênfase em direito constitucional, administrativo e econômico, trabalhos publicados nos seguintes temas: constitucional, administrativo, direito econômico, direitos fundamentais, controle de constitucionalidade, processo constitucional. Instituição: Universidade de Gênova.Brasil. E-mail: anapaula.avila@icloud.com

${ }^{2}$ Médica da Secretaria de Saúde do Município de Porto Alegre. Mestra em Direitos Humanos pelo UniRitter. Doutoranda em Direito na Universidade federal do Rio Grande do Sul. Instituição: Universidade Federal do Rio Grande do Sul. Btasil. E-mail: mandarparakaren@gmail.com

${ }^{3}$ Entre os principais tratamentos da infertilidade incluem-se cirurgias de reversão de Ligadura Tubária e de vasectomia, Inseminação artificial, Fertilização in vitro (FIV) ou Injeção Intracitoplasmática de espermatozoide (ICSI).

${ }^{4}$ A portaria n. 3.149 de 28 de dezembro de 2012 destinou recursos financeiros no valor de $\mathrm{R} \$ 10$ milhões de reais para os estabelecimentos de saúde realizarem procedimentos de atenção à Reprodução Humana Assistida no âmbito do SUS, incluindo FIV e/ou ICSI. (BRASIL, Ministério da Saúde. Portaria n. 3.149 de 28/12/2012. Disponível em: $<$ http://bvsms.saude.gov.br/bvs/saudelegis/gm/2012/prt3149_28_12_2012.html>. Acesso em 13 out 2017.
} 
sistema privado quanto no sistema público de saúde, e as taxas de sucesso por ciclo nos bons serviços podem atingir ou superar levemente as taxas alcançadas de gravidez em casais com fertilidade normal, ou seja cerca de $25 \%$ por tentativa ${ }^{5}$.

Um problema típico decorrente das demandas supervenientes à FIV, enfrentado pelo Supremo Tribunal Federal brasileiro em 2008, decorreu das consequências inerentes às tentativas para engravidar pela técnica, que é o contingente de embriões excedentes que podem ter destinações diversas, a saber: (a) podem ser doados para pesquisas clínicas em células-tronco embrionárias com o intuito de descobrir formas de amenizar e curar diversas patologias degenerativas graves, (b) podem ser criopreservados para utilização pelo casal no planejamento de outros filhos, (c) podem ser doados para outros casais ou (d) simplesmente descartados. A ADI 3.510 questionou a Lei de Biossegurança n. 11.105 de 24 de março de 2005, sendo a decisão majoritária pela constitucionalidade da lei, permitindo as pesquisas com células-tronco. Isso contudo não encerrou as polêmicas sobre o tema; ao contrário, a própria decisão deu-se envolta em aceso debate, chegando-se à decisão final pela diferença mínima de um voto ${ }^{6}$. Agora, por conta da ADPF n. 442, que discute a descriminalização do aborto até a décima segunda semana de gestação, o STF terá de examinar novamente a questão dos direitos reprodutivos e da proteção do início da vida.

As questões suscitadas pela invenção da FIV tocam em questões morais sensíveis. Não há consenso sobre o início da vida ou o momento em que começa a proteção jurídica da vida humana na maioria das sociedades no mundo, e o dissenso sobre o tema perpassa a grande dificuldade de decisões sobre os direitos reprodutivos, de ter ou não ter filhos, de forma segura e com o auxílio da ciência médica. Há divergências de caráter religioso, moral e sociopolítico que se misturam a aspectos ideológicos, psíquicos, científicos, econômicos e bioéticos que convergem numa rede de fascinantes, porém temerárias, discussões sobre cura de doenças, controle de alterações genéticas, escolha de sexo do filho, eugenia, imortalidade etc (WIDER, 2007, p. 1-3).

As discussões e os desdobramentos sobre a questão persistem em todo o mundo e terão seus pontos fundamentais analisados no presente estudo, decorrente do emprego do método de revisão bibliográfica, documental e jurisprudencial, cujo objetivo central é apresentar a definição e o

\footnotetext{
${ }^{5}$ Esclarece-se que mesmo nos serviços de Reprodução Assistida disponíveis pelo SUS, há necessidade do pagamento de valores variáveis para cada tentativa, que são os valores referentes às medicações utilizadas para o estímulo ovariano, há gratuidade dos serviços médicos, punção dos óvulos, ecografias seriadas e toda tecnologia utilizada no procedimento, o valor dos medicamentos usados fica em torno de $\mathrm{R} \$ 5.000,00$ para cada ciclo tentado, com o sucesso em 1 ciclo em torno de $25 \%$. (valor médio divulgado pelo primeiro serviço de Reprodução Assistida pelo SUS em Porto Alegre no H. Fêmina, que funciona desde 2012, em contraposição ao valor particular por ciclo que fica em cerca de R\$ 20.000,00). Disponível em: $<$ http://www.correiodopovo.com.br/Noticias/?Noticia $=400200>$. Acesso em: 13 out 2017.

${ }^{6}$ BRASIL. Supremo Tribunal Federal. Ação Direta de Inconstitucionalidade - ADI 3510 sobre a Lei de Biossegurança. Ministro Relator do Supremo Tribunal Federal - Carlos Ayres Britto. Disponível em < http://www.stf.jus.br/portal/geral/verPdfPaginado.asp?id=611723\&tipo=AC\&descricao=Inteiro\%20Teor\%20AD I\%20/\%203510>. Acesso em 13 out 2017.
} 
conteúdo dos direitos sexuais e reprodutivos e apontar os meios para sua proteção, assim como seu desenvolvimento junto à Corte Interamericana de Direitos Humanos. Tal objetivo será executado em duas partes: na primeira seção, apresentam-se diversas considerações a respeito dos direitos reprodutivos e as implicações bioéticas por eles suscitadas; na segunda seção, analisa-se uma demonstração do encaminhamento que esses direitos tiveram perante à Corte no Sistema Interamericano de Direitos Humanos, a partir de um estudo de caso envolvendo o Estado da Costa Rica, que proibia as técnicas de reprodução assistida no país, negando direitos reprodutivos a casais inférteis sob a alegação da proteção da vida humana desde a concepção, considerada de forma absoluta desde a formação do embrião com a união do óvulo com o espermatozoide. A análise da decisão da CIDH nesta questão poderá lançar luzes sobre o debate do aborto que se encontra em curso perante o Supremo Tribunal Federal.

\section{Considerações sobre os direitos sexuais e reprodutivos e os marcos do início da vida}

\subsection{Reconhecimento e desenvolvimento normativo dos direitos sexuais e reprodutivos nos planos internacional e interno:}

O reconhecimento e a defesa dos direitos sexuais consistem numa das mais relevantes pautas da agenda feminina, que conta já com um longo, porém lento, desenvolvimento nos últimos séculos. Nos primeiros documentos históricos do século XVIII, ainda no processo de constitucionalização dos direitos fundamentais, a desigualdade entre os sexos era considerada natural. Na Declaração de Direitos do Homem e do Cidadão pelos revolucionários franceses de 1789, as reclamações das mulheres quanto à injusta relação de inferioridade na comparação com os homens não foram ouvidas. O Marquês de Condorcet, revolucionário francês e defensor da cidadania das mulheres, em 3 de julho de 1790 publicou na imprensa um artigo intitulado "Sobre a admissão das mulheres ao direito de cidadania" ${ }^{7}$, sendo ignorado pela Assembleia Nacional. No ano seguinte, em 1791, Olympe de Gouges, pseudônimo da ativista política feminista Marie Gouze, divulgou sua "Declaração dos Direitos da Mulher e da Cidadã”, espelhada na Declaração de 1789, prevendo em seu artigo X que "a mulher tem o direito de subir ao cadafalso", tanto quanto o "direito de subir à tribuna”. Olympe, contudo, foi morta na guilhotina sem ter passado pela tribuna. Em 1792, outra feminista da época, Mary Wollstonecraft, na efervescente Paris do período

\footnotetext{
${ }^{7}$ Ver documento do Marquês de Condorcet considerado um defensor da equidade entre homens e mulheres em: http://oll.libertyfund.org/titles/condorcet-on-the-admission-of-women-to-the-rights-of-citizenship. Acesso em 5 nov 2017.
} 
revolucionário escreveu outra obra em defesa dos direitos da mulher: A Vindication of the Rights of Women $^{8}$ (COMPARATO, 2017, p. 149). Segundo Avila e Vilela,

Essa primeira fase do feminismo centrava sua luta em temas como acesso à educação, direito ao voto e igualdade no matrimônio, defendendo a igualdade geral de direitos. Contudo, a sociedade ainda aderia a um modelo convencional de desigualdade fundamentada na vocação "natural" da mulher, concentrando seu discurso na feminilidade e maior sensibilidade das mulheres nos papéis de mãe e esposa, pois seu propósito principal ainda seria servir ao homem e à família (AVILA e VILELA, 2017, p. 1612).

Com efeito, a desigualdade na vida civil entre homens e mulheres só começou a arrefecer em alguns países no século XX. Em 1979 foi celebrada, junto à Organização das Nações Unidas (ONU), a "Convenção sobre a eliminação de todas as formas de discriminação contra a mulher" (CEDAW). A questão suscita um debate travado no âmbito dos direitos humanos pela depuração conceitual entre o que são desigualdades e o que constituem diferenças: no caso das desigualdades existe uma situação de superioridade/inferioridade entre as pessoas implicando a negação da igualdade fundamental de todos, portanto essa desigualdade implica na desconsideração da dignidade de uns para com os outros. Já as diferenças entre as pessoas expressam a riqueza da diversidade dos seres humanos (COMPARATO, 2017, p. 304-306). O ponto de contato entre diferenças e desigualdades é que, ao longo do tempo, os diferentes sempre emulam desconfiança, podendo-se perceber na raiz da desigualdade alguma diferença biológica, cultural, patrimonial; e, conforme Comparato: "Sem a existência de sexos, raças ou culturas diferentes, a humanidade perderia toda a sua capacidade evolutiva e criativa. Por isso, enquanto as desigualdades devem ser perpetuamente combatidas, as diferenças, quando não contrárias à dignidade humana, hão de ser estimuladas e apoiadas" (2017, p. 306),

Paralelamente à igualdade com relação aos homens no acesso à educação e ao voto, a luta feminina reivindicava também o direito ao controle de natalidade e ao próprio corpo. Nesse contexto se inserem os "direitos sexuais e reprodutivos", expressão que refere um conjunto de direitos básicos para a garantia do exercício da sexualidade e da reprodução humana, para isso deve haver acesso à saúde, à informação, à educação e aos meios para o livre planejamento familiar, quer seja para evitar filhos, quer seja para tê-los de forma segura. Além disso, entre a maternidade, tida como uma obrigação social quase compulsória no passado, e a contracepção, que passou a representar uma forma de liberdade para a mulher, percebeu-se que as questões são mais complexas e envolvem

\footnotetext{
${ }^{8}$ Esta obra, um dos mais relevantes documentos históricos da luta feminista, tem versão em PDF que pode ser encontrada online no sítio: $<$ http://www.earlymoderntexts.com/assets/pdfs/wollstonecraft1792.pdf $>$ Acesso em 5 nov 2017.
} 
uma interligação entre maternidade, contracepção e aborto, de modo que negligenciar algum desses elos coloca a mulher em desvantagem (PIOVESAN e PIROTTA, 2017, p. 447-448).

Os direitos reprodutivos são muito caros para os movimentos de defesa dos direitos das mulheres porque a incumbência de prevenir uma gestação indesejada é um encargo tradicionalmente suportado pela mulher, assim como lidar com as repercussões da falha dos contraceptivos, ao ter que gerar um filho e criá-lo, ou mesmo nos casos em que busca interromper a gestação e não encontra respaldo legal na maior parte dos países latino-americanos, onde a permissão para o procedimento do aborto é restrita. Modernamente, embora a ciência médica indique percentuais similares de fatores masculinos e femininos dentre as causas de infertilidade do casal, é sobre a mulher que recai a maior parte da culpa por não conseguir gerar um filho e, mesmo que a infertilidade seja de causa exclusivamente masculina, ainda assim, é o corpo da mulher que padecerá com os efeitos das injeções hormonais e os procedimentos médicos mais invasivos na busca por ter um filho.

Há dois marcos legais internacionais sobre os chamados novos direitos promovidos pela Organização das Nações Unidas (ONU), envolvendo especificamente os direitos sexuais e reprodutivos. O primeiro, a Conferência Internacional sobre População e Desenvolvimento (CIPD), realizada no Cairo em 1994 e reconhecida por 184 Estados, salientou a importância dos direitos sexuais e reprodutivos, reconhecendo que, diante deles, não se fala mais em restrições ao crescimento populacional para o combate da pobreza e desigualdade: a prioridade é o desenvolvimento do ser humano, dando-se início a uma agenda inclusiva de questões sobre a mulher, sobre a população e desenvolvimento, desigualdades de gênero, meio ambiente e Direitos Humanos. No relatório da CIPD de 1994, a Plataforma do Cairo, no seu capítulo II e princípio 4 afirma:

O progresso na igualdade e equidade dos sexos, a emancipação da mulher, a eliminação de toda espécie de violência contra ela e a garantia de poder ela própria controlar sua fecundidade são pedras fundamentais de programas relacionados com população e desenvolvimento. Os direitos humanos da mulher e da menina são parte inalienável, integral e indivisível dos direitos humanos universais. A plena e igual participação da mulher na vida civil, cultural, econômica, política e social, nos âmbitos nacional, regional e internacional, e a erradicação de todas as formas de discriminação com base no sexo são objetivos prioritários da comunidade internacional. (NATIONS, 1994).

A CIPD também realizou uma ampliação e ratificação do conhecido conceito de saúde da Organização Mundial da Saúde (OMS), definido em 1988 e transposto para o conceito de saúde 
reprodutiva de 1994 no Cairo, reivindicando a priorização desses direitos pelos Estados, direcionando sua atenção por meio de políticas públicas que promovam impacto significativo nos direitos da mulher como um todo. Tendo em vista esta pauta, definiu-se que

a saúde reprodutiva é um estado de completo bem-estar físico, mental e social, em todos os aspectos relacionados com o sistema reprodutivo e as suas funções e processos, e não de mera ausência de doença ou enfermidade. A saúde reprodutiva implica, por conseguinte, que a pessoa possa ter uma vida sexual segura e satisfatória, tendo autonomia para se reproduzir e a liberdade de decidir sobre quando e quantas vezes deve fazêlo. [...] saúde reprodutiva é definida como a constelação de métodos, técnicas e serviços que contribuem para a saúde e o bem-estar reprodutivo, prevenindo e resolvendo problemas de saúde reprodutiva. (BRASIL, 2013, p. 13).

O segundo marco legal a ser considerado é a IV Conferência Mundial sobre a Mulher, realizada em Pequim no ano seguinte (1995), na qual os compromissos anteriormente assumidos no Cairo foram reforçados e houve progresso no enquadramento dos direitos sexuais e reprodutivos como Direitos Humanos (BRASIL, 2013, p. 12). A progressiva importância atribuída a esses direitos não é demasia: o menoscabo com os direitos reprodutivos da mulher restringe muito as suas chances de exercer a cidadania no âmbito público e de ter autonomia e liberdade plena no âmbito privado, além do acesso à educação e exercício de direitos políticos e econômicos. Enquanto o CIPD inovou introduzindo o tema espinhoso do aborto, ao indicá-lo como um grave problema de saúde pública, a Plataforma de Ação de Pequim avançou nesse sentido recomendando aos Estados revisarem sua legislação e as respectivas sanções impostas às mulheres que recorrem à ilegalidade para fazer o aborto. (PIOVESAN e PIROTTA, 2017, p. 450 e 454).

Mais recentemente, em reunião em Yogyakarta, na Indonésia, em novembro de 2006, adotaram-se os Princípios de Yogyakarta sobre a Aplicação da Legislação Internacional de Direitos Humanos sobre a Orientação Sexual e Identidade de Gênero. Ainda em 2006, a Convenção sobre os Direitos das Pessoas com Deficiência foi adotada pela ONU, e entre suas recomendações consta a necessidade de promoção de programas de saúde pública para assistência na saúde sexual e reprodutiva das pessoas com deficiência. Em julho de 2008, o Congresso Nacional Brasileiro aprovou o texto da Convenção e seu protocolo facultativo, que foram incorporados no ordenamento jurídico pelo do Decreto Legislativo $n^{\circ} 186$ (BRASIL, 2008) na forma do procedimento do art. $5^{\circ}$, $\S 3^{\circ}$, da CF/88, o qual deu à Convenção sobre os Direitos das Pessoas com Deficiência o status de norma constitucional.

Voltando-se agora para o direito interno, a Constituição da República Federativa do Brasil de 1988 (CF 88) emana para os direitos reprodutivos, assim como para os direitos fundamentais e à ordem jurídica nacional de forma abrangente, o princípio do inciso III do art. $1^{\circ}$, que estabelece como um dos fundamentos da República a dignidade da pessoa humana, núcleo essencial ou pedra 
angular na origem de cada direito materialmente fundamental, consagrando a existência de uma área de integridade que deve ser protegida a todas as pessoas, unida à tutela da liberdade, da igualdade e de um mínimo que garanta mesmo a existência humana (BARROSO, 2011, pp. 272274).

No catálogo de direitos fundamentais da CF 88, no art. $5^{\circ}$, o caput dispõe: “Todos são iguais perante a lei, sem distinção de qualquer natureza, garantindo-se aos brasileiros e aos estrangeiros residentes no País a inviolabilidade do direito à vida, à liberdade, à igualdade, à segurança [...]". Dos 78 incisos deste artigo destacam-se: o inc. I : "homens e mulheres são iguais em direitos e obrigações, nos termos desta Constituição"; o inc. X que garante a proteção da intimidade, vida privada, honra, imagem; o inc. XIV garante a todos o acesso à informação; o inc. XXXIII fala sobre o direito a receber informações de seu interesse particular, coletivo ou geral por parte dos órgãos públicos; inc. XLI estabelece a punição a discriminações a direitos e liberdades fundamentais; no inc. L a garantia de ficar com os filhos no período da amamentação para as presidiárias. De toda forma o rol do artigo $5^{\circ}$ não é taxativo, havendo direitos fundamentais incluídos noutras partes da Carta, ou reconhecidos a partir da cláusula de abertura inclusiva de direitos que decorram do regime e princípios adotados pela República ou dos tratados internacionais aos quais o Brasil manifeste adesão (BRASIL, 2012).

Embora não seja pertinente aqui relacionar todos os direitos constitucionais que integram a agenda da mulher ${ }^{9}$, cumpre referir que relacionam-se diretamente com a questão dos direitos sexuais e reprodutivos o art. 196, impondo ao Estado, mediante políticas públicas, a promoção, proteção e recuperação da saúde, direito de todos e com acesso universal e igualitário; e o art. 198 que determina a descentralização, integralidade e a participação da comunidade nas ações e serviços públicos de saúde, cuja regulamentação ordinária segue o informado na Lei n. 8.080 de 1990. Ainda, o art. 201, inc. II, afirma a proteção "à maternidade, especialmente à gestante"; o art. 203, inc. I, estabelece com um dos objetivos da República "a proteção à família, à maternidade, à infância, à adolescência e à velhice”, proteção que é reforçada como no art. 226, indicando a família como base da sociedade e merecedora de especial proteção estatal.

É ainda necessária uma breve análise de legislação infraconstitucional brasileira devido aos seus reflexos nos direitos sexuais e reprodutivos. O Código Penal brasileiro, Decreto-Lei n.

\footnotetext{
${ }^{9}$ Ainda na $\mathrm{CF} / 88$ podem ser ressaltados o art. $6^{\circ}$ que garante os direitos sociais como a educação, a saúde e a proteção à maternidade dentre outros, no art. $7^{\circ}$ enumerando direitos trabalhistas, no inc. XVIII assegura a "licença à gestante, sem prejuízo do emprego e do salário [...]", no Ato das Disposições Constitucionais Transitórias (ADCT) art. 10, inc. II, alínea b protege a empregada gestante desde a confirmação da gravidez até cinco meses depois do parto contra a dispensa arbitrária, o inc. XIX do art. $7^{\circ}$ da constituição também dispõe sobre a licençapaternidade, da mesma forma afirmada na ADCT no art. 10, inciso II, alínea $b, \S 1^{\circ}$. Assistência gratuita e creches para os filhos até os 5 anos, no inc. XXV e proibição de diferença salarial por motivo de sexo no inc. XXX, ambos no art. $7^{\circ}$
} 
2.848/1940, regulamenta o aborto como crime nos arts. 124 a 127 e, ressalva os casos em que o ato não deve ser punido no art. 128 do mesmo diploma. Constituem os casos do denominado "aborto legal"10: i) aqueles abortos necessários para salvar a vida da gestante, chamado aborto necessário; ii) os que forem praticados nos caso da gestação resultante de estupro, chamado aborto sentimental; e, a partir da ADPF $54^{11}$ de 24/4/2012, conforme decisão do STF iii) a interrupção da gestação nos casos de fetos anencéfalos, foi acrescentada no rol que considera a conduta atípica, tendo autorização legal para ser efetuado (BRASIL, 1940).

O Planejamento Familiar no Brasil é regulamentado pela Lei n. 9.263/1996, a qual define no art. 10 as situações em que é possível a esterilização voluntária: pessoas com capacidade civil plena e maiores de 25 anos ou com dois filhos vivos. Do momento em que a pessoa decide pela contracepção definitiva, não querendo ter filhos ou aduzindo que sua prole está completa, deve decorrer, até o ato cirúrgico, o prazo de 60 dias, período em que a lei determina que equipe multidisciplinar fará acompanhamento visando desencorajar a cirurgia definitiva precocemente. Também pode ser indicada a esterilização se houver risco à vida ou à saúde da mulher ou de um futuro concepto, nesses casos deve ser elaborado relatório escrito, testemunhado e assinado por dois médicos. Importância indiscutível tem o registro da manifestação da vontade da pessoa que se submeterá à cirurgia, autorizando em documento assinado, após prestadas as informações pertinentes, efeitos colaterais, dificuldades de reversão e a indicação de que foi ofertada contracepção de uso contínuo ou não-definitiva antes da esterilização definitiva ser marcada (BRASIL, 1996). Como decorrência, o descumprimento da lei de planejamento familiar enseja o cometimento de lesão corporal grave, incursa no art.129 do Código Penal pela perda permanente da função reprodutiva, crime ao qual se impõe a pena de reclusão de dois a oito anos, além de multa, tendo aumento de um terço da pena se a esterilização for feita no período de parto ou aborto, ou indicada a cesariana com o fim exclusivo para realização da ligadura tubária, uma vez que a lei veda a esterilização nos períodos de parto ou aborto, a não ser se comprovada a necessidade. É procedimento de notificação compulsória à direção do Sistema Único de Saúde.

Finalmente, cumpre observar que, apesar da regulamentação existente, de nada vale um sistema de leis protetivas de direitos fundamentais se esta rede de proteção é desconhecida de toda a gente. $\mathrm{O}$ alerta pode ser ilustrado por dois exemplos atuais: a primeira situação relaciona-se ao desconhecimento geral, tanto das pessoas convivendo com o vírus do HIV quanto dos profissionais da saúde, quanto a uma das estratégias de prevenção combinada instituída no Sistema Único de Saúde, chamada PEP - Profilaxia Pós-Exposição -, que é o uso de antirretrovirais após situações

10 Sobre aborto legal, blog com explicação didática disponível em: $<$ https://drauziovarella.com.br/mulher2/aborto-legal/>. Acesso em 5 nov 2017.

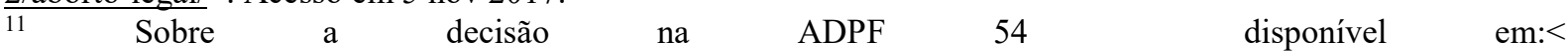


em que houve risco de contato com o vírus do HIV. Iniciando o uso em até 72 horas da exposição, consegue-se reduzir o risco de contágio em percentuais próximos a $100 \%$, e o recurso está disponível para uso nos casos de parceiros sorodiscordantes (um tem o vírus e o outro não) em que houve o rompimento do preservativo, relações desprotegidas no geral, acidentes ocupacionais com instrumentos pérfuro-cortantes ou contato direto com material biológico ( v.g. espirros de sangue nos olhos), tomam-se um ou mais comprimidos ao dia por 28 dias. ${ }^{12} \mathrm{O}$ outro exemplo é o do "aborto legal"13, na mesma tendência de desinformação, há mulheres que ignoram seus direitos a realizarem o aborto, se assim o quiserem e for caso de violência sexual, risco de vida para a mulher e feto anencéfalo, podendo ser realizado até a vigésima semana, mas preferencialmente até as 12 semanas de gestação, assim como parte significativa de profissionais da área da saúde e de médicos ginecologistas, que desconhecem a legislação e os encaminhamentos a serem feitos - e, no casos dos ginecologistas a própria obrigação de realizar o aborto, se for o único profissional na única instituição de saúde com capacitação ao procedimento, independente da objeção de consciência neste caso. Há desconhecimento também quanto a não haver necessidade da apresentação de boletim de ocorrência para realização do aborto nos casos de violência sexual e, da mesma forma, que se prescinde à autorização judicial nesses casos.

De fato, em agosto de 2013 foi sancionada a Lei n. 12.845/2013 que regulamenta os fluxos para o atendimento obrigatório e integral de pessoas em situação de violência sexual ${ }^{14}$, pressupondo-se que venha, inclusive, a reduzir os casos de necessidade de aborto e o risco de infecções sexualmente transmissíveis, pois o atendimento precoce com as medicações conhecidas como "pílulas do dia seguinte", o já mencionado PEP, a administração de antibióticos para infecções sexualmente transmissíveis e de medidas como atendimento psicológico, reduzem significativamente as consequências da violação ao corpo da mulher. Contudo, para a efetividade dessas medidas, as pessoas devem ser informadas da existência da lei, da implementação dos

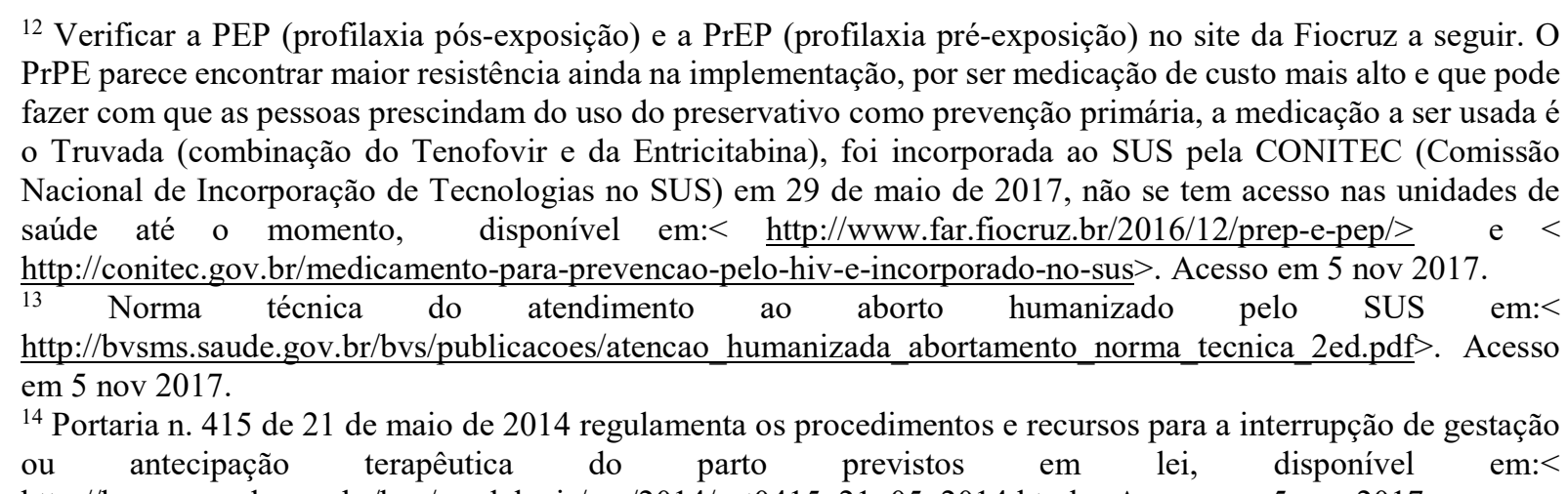
http://bvsms.saude.gov.br/bvs/saudelegis/sas/2014/prt0415 21_05_2014.html>. Acesso em 5 nov 2017. 
serviços em boa parte das capitais e algumas cidades do interior e que, portanto, pode ser exigido o atendimento. ${ }^{15}$

Essas leis concernentes à proteção dos direitos humanos e fundamentais sexuais e reprodutivos presentes nos níveis nacional e internacional, contudo, não eliminam diversas controvérsias sensíveis quanto à reprodução assistida e a relação da fertilidade. Com efeito, quer diante de uma gestação indesejada, em que algumas mulheres reivindicarão o aborto, quer diante da situação de uma gravidez muito desejada que não acontece naturalmente, em que as mulheres são levadas a buscarem as técnicas de fertilização, há intenso debate sobre valores importantes para o direito que norteiam a regulamentação ou proibição do direito humano reprodutivo, cerceando ou ampliando a autonomia plena ao próprio corpo da mulher em contraposição à proteção da vida do nascituro, o que nos leva a necessidade de compreensão dos conceitos relacionados aos marcos vitais.

\subsection{A discussão sobre os marcos do início da vida}

Um dos temas centrais da bioética diz respeito ao momento em que se inicia a vida humana. Se a vida começasse na fecundação, poderia dizer-se que uma parte considerável dos seres humanos morre nos primórdios da vida. Essa afirmação leva em conta a taxa de abortamento espontâneo verificado, em torno de 15 a 20\%, com estimativa de que seja bem maior devido ao fato de que muitas mulheres sofrem sangramentos anormais que constituem abortos sem ter sido feito o diagnóstico de gravidez (FREITAS, MARTINS-COSTA, et al., 2011, p. 97).

Os conhecimentos científicos mostram que a fecundação ocorre com a fusão do óvulo com o espermatozoide desencadeando um novo ser, com um código genético próprio, e a continuidade do desenvolvimento após a união dos gametas formará o embrião, o feto e o recém-nascido. Os dados biológicos indicam que desde o começo o embrião é humano, mas não se pode dizer que é uma pessoa pois esta é uma noção filosófica e este aspecto escapa ao objeto das ciências biológicas (ZINNY, 2004, p. 92).

A teoria genética da união dos gametas formando um embrião é a adotada pela Igreja Católica, que considera este o início da vida a ser protegida, ironicamente valendo-se do conhecimento científico biológico desenvolvido a partir da criação do microscópio, inspirado na invenção do telescópio do astrônomo Galileu Galilei - ele próprio considerado um herege pela Igreja Católica (MUTO e NARLOCH, 2005). As implicações da adoção desta teoria são a

\footnotetext{
${ }^{15}$ No Rio Grande do Sul os serviços de referência para atender as vítimas de violência sexual são: Hospital Presidente Vargas e Porto Alegre, Hospital de Clínicas de Porto Alegre, Hospital Conceição em Porto Alegre, Hospital Fêmina em Porto Alegre, Hospital Universitário de Canoas e o Hospital Geral de Caxias do Sul. 
condenação do aborto em todas as situações e igualmente o rechaço da manipulação ou o descarte de embriões e células-tronco.

Alguns cientistas negam a definição do embrião como um indivíduo porque após a formação inicial da fusão de um óvulo com um espermatozoide, até as primeiras duas semanas, este embrião poderia se dividir e formar dois embriões, ambos com a mesma informação genética que o originário. Se há a possibilidade de um embrião dividir-se até o $13^{\circ}$ dia, em regra, e vir a formar dois outros, não se pode dizer que após a concepção há um indivíduo. Outro marco a contrariar a individualidade do embrião é que nas duas primeiras semanas ele não passa de um aglomerado indiferenciado de células e somente a partir deste momento, passarão a se diferenciar assumindo funções próprias de um ser, não se podendo falar em indivíduo antes disso (ZINNY, 2004, p. 9293).

Alguns biólogos referem-se ao marco de desenvolvimento do sistema nervoso do embrião, que ocorre na oitava semana de desenvolvimento gestacional, quando a atividade elétrica cerebral é encontrada no eletroencefalograma - seria um pressuposto filosófico para considerar-se o embrião como pessoa. Já para outros biólogos, a vigésima semana, quando o feto é capaz de ter sensações, memória, aprendizagem, é o momento de considerá-lo pessoa (ZINNY, 2004, p. 93-95).

A visão neurológica parte do mesmo princípio da determinação da morte: se não há mais vida quando cessa a atividade cerebral, o começo da vida corresponde ao desenvolvimento da atividade cerebral; neste critério neurológico não há unanimidade científica, pois pode-se detectar os primeiros sinais cerebrais na oitava semana, ou de forma mais desenvolvida com vinte semanas. Uma outra visão, ecológica, considera a possibilidade de sobrevivência fora do útero ${ }^{16}$ para determinar o início da vida; sendo assim, um bebê prematuro inicia o amadurecimento pulmonar em torno das 22-24 semanas de gravidez, e se a gestação fosse interrompida neste período ele teria capacidade de sobrevivência extrauterina, necessitando ou não de suporte médico (BARCHIFONTAINE, 2010, p. 44).

Alguns estudos científicos realizados nos Estados Unidos investigam o momento em que ocorre o início da percepção de dor pelo feto. Há um estudo de revisão do ano de 2005 concluindo que, como a percepção de dor necessita de reconhecimento consciente ou consciência de um estímulo nocivo, os reflexos de retirada ou as respostas ao estresse hormonal fetal (vistos quando a

\footnotetext{
${ }^{16}$ Este foi o critério adotado pela Suprema Corte dos EUA no caso Roe vs Wade, decisão que autorizou o direito ao aborto em 1973; com a tecnologia da época a viabilidade fetal fora do útero era a partir das 28 semanas, parâmetros modificados no precedente Planned Parenthood vs Casey em 1992, que definiu como limite à viabilidade fetal as 22-23 semanas, momento em que as UTI's neonatais mais desenvolvidas já suportariam a sobrevivência do feto; a partir destas idades gestacionais os estados americanos poderiam legislar em favor do feto e proibindo a interrupção da gravidez. Além disso, foi o argumento adotado por alguns Ministros na ADPF 54, julgada pelo STF, ao autorizar o abortamento, ou "antecipação terapêutica do parto", nos casos de anencefalia fetal, considerando-se a inviabilidade comprovada de vida extrauterina nesses casos.
} 
mulher grávida passa por procedimentos invasivos), não demonstram a existência de dor fetal porque são respostas que acontecem independentemente de estímulos dolorosos, uma vez que essas respostas não requerem processamento cortical consciente. Assim, para que haja a consciência fetal aos estímulos nocivos, é necessário que o feto já tenha conexões córtico-talâmicas funcionais, e estas fibras somente surgem entre 23 e 30 semanas de idade gestacional; além disso, exames de eletroencefalografia feitos em bebês recém-nascidos em prematuridade extrema, sugerem que a capacidade de percepção funcional da dor provavelmente não existe antes das 29 ou 30 semanas de gestação (LEE, RALSTON, et al., 2005, p. 947-954).

Nos Estados Unidos, o debate sobre o início da vida conta com maior amadurecimento argumentativo devido à permissividade do aborto há mais de 40 anos, por decisão da sua Suprema Corte. Mesmo assim, naquele país antagonizam-se os grupos pro choice, a favor do aborto e o direito de escolha da mulher, e os grupos pro life, contrários ao procedimento e em defesa da vida do nascituro de forma absoluta e, diante dessa rivalidade, qualquer dado científico ${ }^{17}$ incendeia $o$ debate. Assim, esses grupos usam as pesquisas que mais se amoldam às bandeiras defendidas; de um lado, os que defendem a escolha da mulher em interromper uma gestação indesejada podem usar a conclusão de que o feto não tem consciência da dor antes de pelo menos 20 semanas para dizer que a escolha pelo aborto tem ascendência sobre a vida fetal; de outro lado, as pesquisas mais antigas, propiciadas pelos primeiros instrumentos de magnificação da imagem que permitiram verificar que a união entre um óvulo e um espermatozoide é a origem do ser humano, consubstanciam o conhecimento científico que mais convém aos que defendem a vida desde a concepção com a consequentemente proibição do aborto.

A propósito do conhecimento científico, numa análise sobre a fluidez e o relativismo que marcam a modernidade, Giddens (1991, p. 49-50) observa que "a equação entre conhecimento e certeza revelou-se erroneamente interpretada", pois ao mesmo tempo em que vivemos este mundo constituído por conhecimento aplicado de forma reflexa, ainda assim "não podemos nunca estar seguros de que qualquer elemento dado deste conhecimento não será revisado”. Sobre a ciência, registra:

Mesmo os filósofos que mais ferrenhamente defendem as reivindicações da ciência à certeza, tais como Karl Popper, reconhecem que, como ele o exprime, "toda ciência repousa sobre areia movediça". Em ciência, nada é certo, e nada pode ser provado, ainda que o empenho científico nos forneça a maior parte da informação digna de confiança sobre o mundo a que podemos aspirar. No coração do mundo da ciência sólida, a modernidade vagueia livre (GIDDENS, 1991, p. 50, grifo do autor).

17 Sobre a questão da dor fetal nas considerações de se permitir ou não o aborto, mais em:< http://www.nytimes.com/2013/09/17/health/complex-science-at-issue-in-politics-of-fetalpain.html?pagewanted=2\& r=1\&>. Acesso em 5 nov 2017. 
Essas teses sobre os marcos iniciais da vida, para Gloria Zinny (2004, p. 93-95), são empíricas e acabam sendo reducionistas ao prenderem-se a determinadas funções e ao desenvolvimento embrionário-fetal. Mesmo que o embrião não seja uma pessoa plena, não obstante, se o desenvolvimento natural ocorrer, será uma criança e depois um adulto, razão por que merece algum grau de cuidado. Para a autora, a biologia e a filosofia são impotentes para decidir categoricamente sobre o status do embrião, sendo, portanto, a ética e o direito que delimitarão as proteções e o respeito devidos ao embrião.

Em certa consonância com a conclusão de Zinny sobre a importância da ética e do direito para a definição das polêmicas advindas do desenvolvimento científico, que não encontra certezas na própria ciência, Giddens (1991, p. 32-33) aduz que, a despeito das ciências sociais serem vistas como uma "prima pobre" das ciências naturais (principalmente em decorrência do grandioso desenvolvimento técnico-científico moderno), são justamente as ciências sociais as que estão mais implicadas nas questões da modernidade, "na medida em que a revisão crônica das práticas sociais à luz do conhecimento sobre estas práticas é parte do próprio tecido das instituições modernas".

Em acréscimo, o grande - e descontrolado - desenvolvimento tecnológico deflagra na sociedade um processo chamado "coisificação", levando a crer que há possibilidades de se comprar "mercadorias e serviços - de valores muito desejados, como saúde, felicidade, amor e satisfação" (LEFEVRE e LEFEVRE, 2009, p. 21). O produto disso é que os projetos de vida deixam de significar fins que dão sentido à existência humana e o indivíduo se aliena e passa a ser um "objeto dos meios, isto é, dos sentidos impregnados nos objetos e serviços oferecidos no mercado para serem comprados" (2009, p. 22, ibidem, grifo do autor).

Nessa linha, Jürgen Habermas (2010, p. 25-29) aponta uma ampla mercantilização no campo da pesquisa biogenética e uma forte pressão sobre os governos nacionais que acaba por impor modificações aos processos legislativos, que deliberam sem os devidos esclarecimentos na esfera pública. O lobby da técnica genética pode fazer com que determinadas práticas tornem-se habituais sem uma análise detida das implicações morais; vejam-se, por exemplo, as técnicas seletivas que avaliam o embrião antes da sua implantação no útero:

É compatível com a dignidade humana ser gerado mediante ressalva e, somente após um exame genético, ser considerado digno de uma existência e de um desenvolvimento? Podemos dispor livremente da vida humana para fins de seleção? [...] Na medida em que a produção e a utilização de embriões para fins de pesquisas na área médica se disseminam e se normalizam, ocorre uma mudança na percepção cultural da vida humana 
pré-natal e, por conseguinte, uma perda da sensibilidade moral para os limites dos cálculos do custo-benefício.

Todas essas questões - das controvérsias sobre o status do embrião ao momento em que tem início a vida humana -, estão presentes quando se trata de reconhecer a todos, na condição de direitos humanos, os direitos sexuais e reprodutivos. O modo como esses dados se articulam na concretização desses direitos é algo para ser examinado no âmbito da atuação das Cortes encarregadas da sua proteção. Daí a relevância em examinarmos os precedentes disponíveis, como é o caso da decisão da Corte Interamericana no Caso Artavia Murillo e outros versus Costa Rica, que opera, na prática, a conexão das questões enfrentadas até aqui.

\section{Parâmetros jurídicos para a proteção dos direitos sexuais e reprodutivos no âmbito da bioética: um estudo de caso}

\subsection{O Caso Artavia Murillo e outros vs. Costa Rica}

O caso Artavia Murillo refere-se a um grupo de casais que ingressou contra o Estado da Costa Rica por apresentarem dificuldades relacionadas à fertilidade e, em decorrência disso, sofreram prejuízos em seus direitos reprodutivos por causa da proibição das técnicas de Reprodução Assistida no país, uma vez que a impossibilidade de recorrer à Fertilização In Vitro (FIV) cerceou o direito de constituir família por estes casais naquele país (CASTALDI e RAMOS-KURI, 2016, p. 18-20).

Nos primórdios da expansão da utilização das técnicas de reprodução assistida, iniciadas na Inglaterra ${ }^{18}$ e em seguida disseminadas mundo afora, a Costa Rica, por meio do seu Ministério da Saúde, emitiu o decreto executivo n. 240029-S, de 3 de fevereiro de 1995, com a autorização para realização da Fertilização in vitro no país. No entanto, cerca de cinco anos depois, em 15 de março de 2000, a Sala Constitucional da Corte Suprema de Justiça da República da Costa Rica por Resolução declarou a inconstitucionalidade deste decreto executivo, instituindo a proibição da FIV no país a partir de então (CASTALDI e RAMOS-KURI, 2016, p. 18-20).

Grettel Artavia Murillo e seu marido paraplégico não podiam ter filhos, a não ser que recorressem a técnicas de Reprodução Assistida, e, junto a mais 8 casais entraram com petição à Comissão Interamericana de Direitos Humanos em 19 de janeiro de 2001, levando os documentos

\footnotetext{
${ }^{18}$ Louise Joy Brown, com 2,5 kg, foi o primeiro bebê de proveta do mundo, nasceu na Inglaterra através da técnica de FIV desenvolvida pelo cientista Robert Geoffrey Edwards, que ganhou o Nobel de Medicina pelo desenvolvimento da técnica; os pais de Louise tentaram sem sucesso ter filhos por 9 anos antes que pudessem ser os primeiros do mundo a se beneficiarem desta tecnologia. Disponível em: $<\underline{\text { http://acervo.oglobo.globo.com/em- }}$ destaque/com-25-quilos-nasce-primeiro-bebe-de-proveta-do-mundo-na-inglaterra-em-1978-8998193>. Acesso em 9 out 2017.
} 
médicos comprovando as causas diagnosticadas de infertilidade e demonstrando a necessidade de técnicas reprodutivas para que conseguissem a concepção e a constituição de família que desejavam. ${ }^{19} \mathrm{O}$ relatório de admissibilidade saiu três anos após o peticionamento, em 11 de março de 2004, e o de mérito nove anos após, em 14 de julho de 2010. A comissão então pediu à Corte que decidisse se a Costa Rica havia violado os direitos consagrados, principalmente, nos art. 11.2; 17.2 e 24 da Convenção Americana de Direitos Humanos ${ }^{20}$ verbis:

Artigo 11. 2 Proteção da honra e da dignidade: Ninguém pode ser objeto de ingerências arbitrárias ou abusivas em sua vida privada, na de sua família, em seu domicílio ou em sua correspondência, nem de ofensas ilegais à sua honra ou reputação.

Artigo 17. 2 Proteção da família: É reconhecido o direito do homem e da mulher de contraírem casamento e de fundarem uma família, se tiverem a idade e as condições para isso exigidas pelas leis internas, na medida em que não afetem estas o princípio da não-discriminação estabelecido nesta Convenção.

Artigo 24. Igualdade perante a lei: Todas as pessoas são iguais perante a lei. Por conseguinte, têm direito, sem discriminação, a igual proteção da lei.

O Estado da Costa Rica, por sua vez, alegava como fundamento para a proibição da FIV o art. 4.1, da mesma Convenção Americana de Direitos Humanos que dispõe sobre a proteção da vida humana desde sua concepção: “Toda pessoa tem o direito de que se respeite sua vida. Esse direito deve ser protegido pela lei e, em geral, desde o momento da concepção. Ninguém pode ser privado da vida arbitrariamente." ${ }^{21}$ A utilização deste dispositivo para inviabilizar o procedimento da FIV deve-se ao fato de que, para propiciar a geração de um bebê, acaba-se por produzir um grande número de embriões excedentários, ou seja, por cada nascido vivo cerca de até 50 embriões podem terminar sendo descartados (CASTALDI e RAMOS-KURI, 2016, p. 242).

A decisão da Corte Interamericana de Direitos Humanos foi pronunciada em 28 de novembro de 2012 e orientava o Estado da Costa Rica a providenciar o mais rapidamente possível a revogação da proibição da FIV, regulamentando as questões necessárias para a implementação de procedimentos de Reprodução Assistida, tanto a FIV quanto os sistemas de controle da qualidade das instituições que desenvolvessem a técnica, impondo também a prestação de assistência psicológica às vítimas pelo período de quatro anos, bem como o pagamento de uma indenização de

19 CORTE IDH. Ficha técnica do Caso Artavia Murillo y otros vs. Costa Rica. Disponível em:http://www.corteidh.or.cr/cf/Jurisprudencia2/ficha tecnica.cfm?nId_Ficha=235. Acesso em 8 out. 2017.

${ }^{20}$ Convenção Americana de Direitos Humanos (Pacto de São José da Costa Rica) de 22 de novembro de 1969.

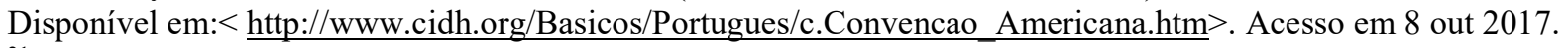

${ }^{21}$ Ibidem. 
25 mil dólares para cada casal demandante. ${ }^{22}$ Cumpre notar que, além destas proposições relacionadas à reparação às vítimas e à revogação legislativa que permitisse a instituição de serviços de Reprodução Assistida no país, a sentença ainda impôs ao Estado da Costa Rica o encargo de disponibilizar a tecnologia reprodutiva em seus programas de saúde pública para o tratamento da infertilidade, de acordo com o dever de garantir o princípio da não discriminação, para aquelas pessoas que não dispusessem de recursos para o tratamento (CASTALDI e RAMOS-KURI, 2016, p. 10).

Para a compreensão mais ampla do significado da sentença do caso Artavia Murillo é necessário se debruçar sobre as técnicas de interpretação utilizadas pela Corte ao desenvolver os seus argumentos na consagração deste que é considerado um dos "novos direitos da agenda contemporânea" (PIOVESAN, 2014, p. 148) pela doutrina internacionalista. A Corte valeu-se da interpretação dos dispositivos da Convenção Interamericana dos Direitos Humanos que foram apresentados para fundamentação tanto dos direitos dos casais que sofriam de infertilidade, quanto por parte do Estado que proibia completamente as técnicas de FIV necessárias à constituição de família por esses casais, o que implicou na análise da proporcionalidade entre os direitos invocados, principalmente no que concerne à ponderação do prejuízo para os casais diante de uma proibição total da utilização de técnicas de reprodução assistida no país, quando comparados com a proteção do direito à vida, desde a concepção, alegada pela Costa Rica (CHIA e CONTRERAS, 2014, p. 570). Por isso a Convenção, segundo a CIDH no caso Artavia Murillo, deve ser interpretada levando-se em conta o sistema de proteção internacional de direitos humanos de forma holística, integral e, principalmente, numa análise evolutiva porquanto as técnicas de reprodução assistida não existiam quando a Convenção foi elaborada (PIOVESAN, 2017, p. 138).

De acordo com o voto majoritário da Corte, a proteção de forma absoluta do embrião, nos termos invocados pela Costa Rica, é desproporcional e restringe de forma excessiva os outros direitos também consagrados na Convenção, como os direitos à integridade pessoal, liberdade de fundar uma família, e vida privada e familiar dos demandantes (CHIA e CONTRERAS, 2014, p. 574). Mesmo sendo uma questão altamente controversa no mundo inteiro, a CIDH assentou que o embrião não é sujeito de direitos, na esteira do entendimento de diversas cortes constitucionais que têm construído a ideia de que o nascituro não é ainda detentor de direitos, senão sob condição suspensiva, não tendo o mesmo status moral que uma pessoa que já tenha nascido (p. 574-579 Ibidem). Portanto, merece uma proteção legal gradativa, na medida em que o nascituro vá

${ }^{22}$ CORTE IDH. "Caso Artavia Murillo y otros ("fecundación in vitro") vs. Costa Rica. (Excepciones Preliminares, Fondo, Reparaciones y Costas)". Sentencia de 28 noviembre de 2012 Serie C No. 257, para. 223. Disponível en:< http://www.corteidh.or.cr/docs/casos/articulos/seriec_257_esp.pdf>. Acesso em 8 out 2017. 
encontrando o nível de desenvolvimento da capacidade de viabilidade fetal ${ }^{23}$, ou seja, mesmo intraútero seja capaz de sobreviver se a gestação for interrompida.

Ao adotar o entendimento de que o embrião não pode ainda ser considerado pessoa, a Corte Interamericana reverbera outra decisão muito emblemática num leading case julgado pela Suprema Corte dos Estados Unidos da América - o caso Roe vs. Wade. Esse precedente, considerando que nenhum dos estados norte-americanos reconhecia que os nascituros tivessem os mesmos direitos e status jurídico que as pessoas já nascidas, julgou que seria desproporcional valorar com maior importância a vida do feto ainda no primeiro trimestre gestacional (sem a menor possibilidade de sobrevivência fora do útero materno), em contraposição à vida da mulher que carregasse este feto, sendo já uma pessoa em sua completude e com status jurídico. Diante disso decidiu que a interrupção da gestação no primeiro trimestre seria possível pois

quando o feto está muito longe de ser aquilo que o Estado trata como uma pessoa humana no sentido jurídico, quando se encontra ainda num estado puramente vegetativo e insensível a todo sentimento, a vida da mulher, para quem um filho indesejado pode resultar em grande sofrimento (inclusive a morte) para ela mesma e para a criança, tem prioridade (BEATTY, 2014, p. 338-340).

A vida humana em estágio embrionário, então, não foi considerada na decisão da Corte como pessoa humana na sua totalidade, antes uma vida em potência, de acordo com o alcance ou o devir de determinados marcos do desenvolvimento fetal. Não pode ser avaliada, portanto, em termos de imposição de tudo ou nada, pressupondo uma gradação de proteção que, neste sentido, encontra inferior peso em contraposição à vida da mulher que albergar esta vida em potência (CHIA e CONTRERAS, 2014, p. 579-580).

A CIDH discorreu ainda sobre uma interpretação fundamental acerca do conceito usual que se tinha da palavra "concepção", estabelecendo uma delimitação mais restrita ao afirmar que o termo concepção, no sentido utilizado no art. 4.1 da Convenção, só poderia ser considerado no momento da implantação do embrião intra-útero. Portanto o estipulado pela Convenção não se aplicaria antes desse momento, os embriões pré-implantatórios excedentes no processo de cada ciclo de tentativas da técnica de FIV não teriam a mesma tutela inscrita no dispositivo citado na Convenção e defendidos pela Costa Rica na demanda (CASTALDI e RAMOS-KURI, 2016, p. 19). Ademais, a alegada "vida humana" a ser protegida desde "o momento da concepção", não poderia ter contemplado o produto da fertilização da união in vitro do óvulo e do espermatozoide porque

\footnotetext{
${ }^{23}$ Viabilidade fetal é a capacidade de um feto sobreviver fora do útero, de acordo com o amadurecimento de seus órgãos e recursos disponíveis para a assistência ao nascido prematuro, as chances de sobrevivência, em regra, iniciam-se em torno das 23-24 semanas e $500 \mathrm{~g}$ do feto, podendo ter alguma variação de acordo com o nascimento em centros urbanos com Unidades de Terapia Intensiva neonatais. (FREITAS, 2011).
} 
tal tecnologia de tratamento para casos de infertilidade não existia ao tempo de elaboração do Pacto de São José da Costa Rica.

Tivemos oportunidade de apresentar no tópico anterior diversos dados que lançam luzes à interpretação conferida pela CIDH à questão: (a) descoberta de como se dá a fertilização só foi demonstrada com o advento do microscópio; (b) somente com a pesquisa científica e a tecnologia foram desvelados alguns dos marcos do desenvolvimento fetal, assim como (c) a grande taxa de desperdícios e perdas em estágio incipiente ocorridas na reprodução humana natural, com até mais de um quarto de todas as gestações terminando em aborto espontâneo. Considerados esses dados em conjunto com a provisoriedade que marca as "verdades" científicas, uma vez que o próprio conhecimento técnico-científico modifica o entendimento após cada nova descoberta, a defesa em termos absolutos de uma vida em potência em contraposição à vontade da mulher, uma pessoa na plenitude de sua vida, ganha conotação pretensiosa e redutora da maior polêmica bioética e filosófica mundial, a despeito de todo conhecimento acumulado até o momento.

Afirmou-se na sentença que o uso da expressão "em geral" no art. 4.1 da Convenção, com relação à proteção do direito à vida, refere justamente um caráter relativo e de incremento gradual, a ser empregado de acordo com o desenvolvimento do nascituro, não sendo assim dever absoluto, tampouco incondicional (CASTALDI e RAMOS-KURI, 2016, p. 19). A sentença da Corte argumentou ainda, referente ao dispositivo 4.1 do Pacto (principal base que fundamentava a resposta do Estado em defesa de sua discricionariedade de proibir a FIV), que o objeto direto de proteção era fundamentalmente a vida da mulher grávida, e que o impedimento total de se fazer FIV no país vulnerava a integridade pessoal, a liberdade, a vida privada e o direito à família dos casais com problemas de infertilidade (2016, p. 19-20, Ibidem). ${ }^{24}$

Analisadas as principais questões interpretativas utilizadas para argumentar a sentença do caso estudado, cumpre refletir sobre o papel que essa decisão pode desempenhar nos sistemas internos dos Estados. Para tanto, analisaremos a teoria dos diálogos jurisdicionais para a compreensão de como operam os subsídios decorrentes da interação entre os diversos diplomas normativos e precedentes internacionais para a decisão emitida pela Corte Interamericana de Direitos Humanos.

\subsection{Diálogos jurisdicionais: reflexos da decisão da CIDH sobre a proteção dos direitos reprodutivos no Brasil}

\footnotetext{
${ }^{24}$ Em que pese a isenção com que o estudo de CASTALDI, Ligia de Jesús et al (2016) descreveram as razões da Corte em sua decisão majoritária de permitir a FIV, o trabalho como um todo direciona seus argumentos frontalmente contra a sentença que consideram um erro, entendem que o art. 4.1 do Pacto de São José da Costa Rica protege a vida embrionária de forma absoluta, criticam fortemente a Corte Interamericana e consideraram a atuação ideológica.
} 
Segundo Piovesan (2017, p. 132-134), o sistema internacional de proteção dos direitos humanos tem uma perspectiva multinível a partir dos diálogos jurisdicionais no sistema global, nos sistemas regionais e com os sistemas nacionais, em que a aplicação do controle de convencionalidade faz a harmonização entre os diplomas internacionais e o doméstico. No Sistema Interamericano interagem Estados, vítimas, organizações da sociedade civil nacionais e internacionais, a Comissão e a Corte Interamericana no âmbito da OEA, de modo que os diálogos entre esses atores incrementam a proteção dos direitos humanos numa perspectiva que Piovesan considera multinível, e a partir dela

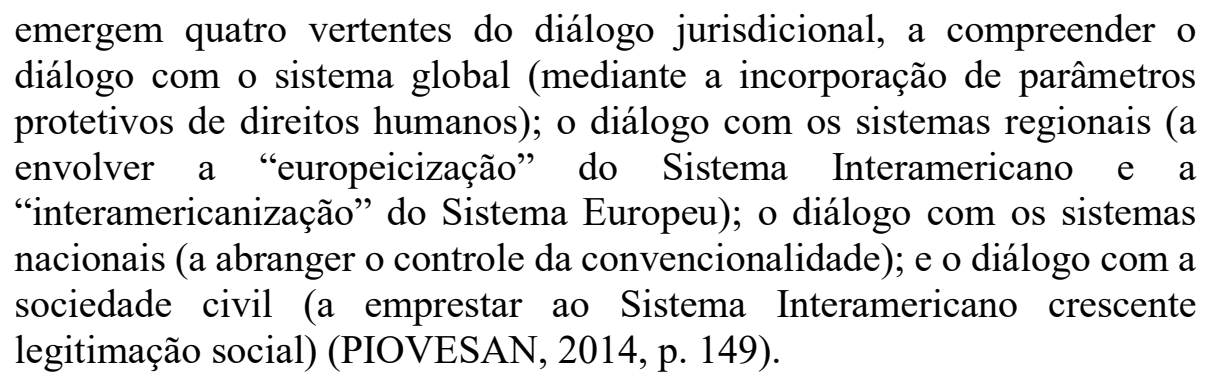

A chamada "interamericanização" consiste no diálogo com o Sistema Europeu e a "europeicização", o diálogo da solução das demandas no Sistema Interamericano, ou seja, encontramos decisões da Corte Europeia sobre direitos sociais referindo-se às sentenças emanadas da Corte Interamericana e vice-versa (PIOVESAN, 2017, p. 136-137). Essa interpenetração entre os diferentes sistemas regionais seria uma consequência natural da pretensão de universalidade conferida à questão dos direitos humanos.

Piovesan refere a existência de uma estrutura legal em forma de trapézio jurídico que é aberto ao diálogo e à interdisciplinaridade, da pirâmide kelseniana que se voltava ao State approach há direcionamento à permeabilidade em trapézio com a priorização humana, human rights approach (2017, pp. 138-139). Além disso, na facilitação dos diálogos entre os sistemas, Piovesan salienta a importância das novas técnicas legislativas utilizadas para a inclusão de dispositivos constitucionais nas Cartas latino-americanas - as chamadas cláusulas abertas - que, através da interpretação e integração, facilitam o respeito à hierarquia dos tratados envolvendo os direitos humanos, assim como a priorização de um dos princípios luminares do direito internacional, o princípio pro persona, que estabelece a prevalência da norma mais benéfica na aplicação do fenômeno do "controle de convencionalidade" entre os sistemas citados (PIOVESAN, 2017, p. 140-141).

Nesse particular, a Constituição Federal de 1988 apresenta dois dispositivos que expressam a assimilação das normas protetivas dos direitos humanos: a cláusula do art. $5^{\circ}, \S 2^{\circ}$, pelo qual o conceito material de direitos fundamentais é aberto e compatível com o reconhecimento desta condição aos direitos decorrentes dos tratados firmados pelo Brasil; e a cláusula do $\S 3^{\circ}$, inserida no $\operatorname{art} .5^{\circ}$ por ocasião da EC n. 45 para não deixar dúvidas de que a hierarquia dos tratados equipara- 
se à das emendas constitucionais sempre que forem internalizados por 3/5 dos parlamentares em dois turnos de votação.

Piovesan (2017, p. 136) vislumbra na decisão proferida no caso Artavia Murillo e outros versus Costa Rica um dos exemplos típicos dos diálogos jurisdicionais, em que a defesa da possibilidade da fertilização in vitro pelos casais foi sustentada pela Corte Interamericana com fundamento em interpretação histórica e sistemática, dialogando com: "a Declaração Universal de 1948, o Pacto Internacional de Direitos Civis e Políticos, a Convenção sobre a Eliminação de todas as formas de Discriminação contra a Mulher e a Convenção sobre os Direitos da Criança”.

No entanto, para além desses diálogos entre diferentes diplomas internacionais, pode-se considerar que a decisão lança argumentos que podem ampliar os atores nesses diálogos, iluminando debates em pleno curso na sociedade, alguns em questões judicializadas, como na ADPF 54 julgada pelo STF que tratava do aborto em caso de anencefalia, no exame das autorizações de interrupção da gestação contraída por pessoa portadora do zika vírus que aguarda julgamento pelo Pleno deste Tribunal ou, mais recentemente no exame da questão do aborto recentemente analisada em audiências públicas realizadas no curso da ADPF 442, sob relatoria da Min. Rosa Weber.

No caso das gestações afetadas pelo vírus da zika, transmitido pelo mosquito Aedes aegypti, a ANADEP (Associação Nacional dos Defensores Públicos), apoiada pelo ANIS, Instituto de Bioética, ingressou com Ação Direta de Inconstitucionalidade - ADI n. 5581 ${ }^{25}$ - cumulada com Arguição de Preceito Fundamental no Supremo Tribunal Federal (STF) em agosto de 2016, questionando políticas públicas contra a epidemia da zika constantes na Lei 13.301/2016, em especial o art. 18, referente aos benefícios assistenciais e previdenciários para as mulheres e para as crianças que foram afetadas pela microcefalia e têm sequelas neurológicas. O ponto mais polêmico, contudo, é o pedido para que os casos de gravidez com confirmação de microcefalia decorrente da infecção pela zika obtenham o mesmo tratamento dado pelo STF no caso dos fetos anencéfalos, ou seja, ofereça-se a essas mulheres a possibilidade do aborto. Parecer da Advocacia-geral foi contrário ao pedido de autorização de aborto nesses casos, alegando as diferenças entre os casos, uma vez que as alterações neurológicas e microcefalia são compatíveis com a vida, o que não era o caso dos fetos anencéfalos; já, o Procurador-Geral da República alegou preliminarmente a ilegitimidade ativa da ANADEP, e postulou a procedência parcial do pedido ao defender o mesmo tratamento dado pelo Supremo aos casos de fetos anencéfalos na ADPF 54 de 2012, autorizando a interrupção da gravidez também nos casos de gestação afetada pela zika. A ação havia sido distribuída para relatoria da Ministra Cármen Lúcia, antes dela assumir a presidência do STF, as últimas

25 Acompanhamento da ADI 5581/2016 no sítio do STF em: $<$ http://www.stf.jus.br/portal/processo/verProcessoAndamento.asp?incidente=5037704>. Acesso em 5 nov 2017. 
movimentações no sítio do STF relacionam muitas petições de amicus curiae, não tendo ainda previsão de ser pautada.

O diálogo que se estabelece entre os organismos internacionais que promovem a celebração de tratados internacionais protetivos de direitos humanos e de direitos das mulheres, entre as Cortes Constitucionais tais como a Suprema Corte dos Estados Unidos e o Supremo Tribunal Federal do Brasil, e as Cortes supranacionais de proteção dos direitos humanos, como a Corte Interamericana e a Europeia de Direitos Humanos, expressam um processo que a doutrina vem denominando de “diálogos jurisdicionais". Neste processo, argumentos e parâmetros interpretativos das disposições normativas atinentes aos direitos sexuais e reprodutivos nas diferentes jurisdições (nacionais e supranacionais) se retroalimentam, criando condições para o aprimoramento das legislações internas dos respectivos países, de modo a assegurar os direitos básicos de igualdade e autonomia dos cidadãos na sua plenitude.

Nada obstante, na contramão do debate travado nesse esquema multinível, encontram-se no Congresso Nacional alguns projetos de lei e propostas de emenda constitucional que visam institucionalizar a criminalização total do aborto e a defesa absoluta da vida do nascituro desde a concepção. O PL 5069 de 2013, de autoria do ex-deputado Eduardo Cunha (PMDB/RJ), um dos líderes que integrava a facção religiosa no Congresso Nacional (a bancada evangélica), tenta alterar a Lei n. 12.845 de 2013, que dispõe sobre o atendimento das vítimas de violência sexual, para dificultar a realização do aborto após o estupro, obrigando exame de corpo de delito e comunicação policial. O ex-deputado também realiza uma verdadeira cruzada sugerindo alterações na lei contra a pílula do dia seguinte, que a bancada considera abortiva, com modificações também de artigos do Código Penal, abrindo brechas para a proibição da pílula do dia seguinte até nas farmácias. A perseguição à pílula, não fosse a própria representação nefasta do retrocesso e da tentativa de retirada de direitos duramente conquistados, seria risível se já não fosse inútil, pois obtém-se o mesmo efeito, com alguns efeitos colaterais a mais, a partir da utilização de qualquer cartela de pílulas anticoncepcionais convencionais, num esquema bastante conhecido por profissionais que se 
dedicam à saúde da mulher. ${ }^{26} \mathrm{O}$ PL já foi aprovado na Comissão de Constituição e Justiça e Cidadania da Câmara dos Deputados, encontra-se pronto para ser pautado e debatido em Plenário. ${ }^{27}$ Já o PL 478 de 2007, da autoria do deputado Luiz Bassuma do PEN/BA e Miguel Martini do PHS/MG, é chamado de "Estatuto do nascituro" e pretende a proteção do direito à vida desde a concepção, além da tipificação do aborto como crime hediondo, retrocedendo portanto até em relação aos casos em que o aborto é permitido desde a elaboração do Código Penal na década de 1940. Em 5 de junho de 2013 o relator da Comissão de Finanças e Tributação, o ex-deputado Eduardo Cunha, aprovou o relatório, encaminhado à CCJC, e lá o relator Marcos Rogério, deputado do DEM/RO e membro da Assembleia de Deus, aprovou parecer em 7 de junho de 2017; porém, após requerimento em plenário do deputado Glauber Braga do PSOL/RJ, o PL foi redistribuído para a Comissão de Defesa dos Direitos da Mulher, onde se encontra. ${ }^{28}$

As PECs $164^{29}$ de 2012, de autoria do ex-deputado Eduardo Cunha, e 29 de 2015, de autoria do senador Magno Malta (PR/ES), pretendem alterar o art. $5^{\circ}$ da CF 1988 para estabelecer a inviolabilidade do direito à vida desde a concepção, ambas ainda sem parecer da CCJC. Em 2016 o atual presidente da Câmara dos Deputados, o Dep. Rodrigo Maia ${ }^{30}$ esbravejou e ameaçou criar

\footnotetext{
${ }^{26}$ Há duas formas de oferecer a anticoncepção de emergência: o método de Yuzpe, utiliza anticoncepcionais orais combinados que possuem estrogênio e progesterona, são de uso rotineiro em planejamento familiar, podem ser usados em até cinco dias após a relação sexual desprotegida, as pílulas que tem dosagem maior: evanor ${ }^{\circledR}$ ou neovlar ${ }^{\circledR}, 2$ comprimidos (12/12 horas) ou 4 comprimidos (dose única); ou as de dosagem média distribuídas em postos de saúde: o microvlar ${ }^{\circledR}$ ou nordette ${ }^{\circledR}, 4$ comprimidos (12/12 horas) ou 8 comprimidos (dose única). A segunda forma, que é o motivo das preocupações da bancada religiosa, é o levonorgestrel, progesterona isolada que provoca menos náuseas e vômitos, na dose total de $1,5 \mathrm{mg}$, dividida em 2 comprimidos iguais de $0,75 \mathrm{mg}$, a

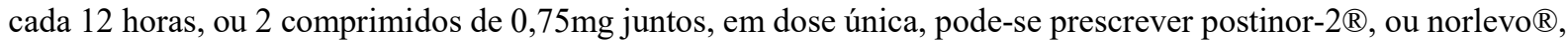
ou pilem $\AA$, ou pozato $\AA$, ou nogravid $\AA$, ou poslov ${ }^{\circledR}, 1$ comprimido a cada 12 horas ou 2 comprimidos em dose única. Disponível em: $<$ http://bvsms.saude.gov.br/bvs/publicacoes/caderno3 saude_mulher.pdf $>$ na pág.8. Acesso em 6 nov 2017.

27 Acompanhamento da tramitação do PL 5069/2013 disponível em:< http://www.camara.gov.br/proposicoesWeb/fichadetramitacao?idProposicao $=565882>$, também sobre o PL: $<$ https://brasil.elpais.com/brasil/2015/11/12/politica/1447357721_656693.html> . Acesso em 6 nov 2017.

28 Acompanhar a tramitação do PL do "Estatuto do nascituro" em: $<$ http://www.camara.gov.br/proposicoesWeb/fichadetramitacao?idProposicao=345103 $>$. Acesso em 6 nov 2017. $290 \begin{array}{llllll}\text { Acompanhar } & \text { a } & \text { PEC } & 164 / 2012 & \text { em: }\end{array}$ http://www.camara.gov.br/proposicoesWeb/fichadetramitacao?idProposicao=543252>; e a PEC 29 do Senado em: $<$ http://www25.senado.leg.br/web/atividade/materias/-/materia/120152> . Acesso em 6 nov 2017.

${ }^{30}$ Ver sobre o fato em: $<$ http://www2.camara.leg.br/camaranoticias/noticias/POLITICA/520372-DEPOIS-DEDECISAO-DO-STF-SOBRE-ABORTO,-MAIA-CRIA-COMISSAO-PARA-DISCUTIR-TEMA.html>. Acesso em 6 nov 2017.

Dados do IBGE divulgados em 2013, indicam que viviam no Brasil 103,5 milhões de mulheres, o equivalente a $51,4 \%$ da população; entre os eleitores, as mulheres também são maioria. Nas eleições de 2014, o Tribunal Superior Eleitoral tinha em seus registros 77.459.424 eleitoras diante de 68.247 .598 eleitores do sexo masculino. Conferir: http://www.brasil.gov.br/cidadania-e-justica/2015/03/mulheres-sao-maioria-da-populacao-e-ocupammais-espaco-no-mercado-de-trabalho Acesso em 11 nov 2017.
} 


\title{
Sexual and reproductive Rights protection at the Inter-American Court of Human Rights and
} the judicial dialogues theory

\begin{abstract}
The article elaborates on reproductive rights and its implications regarding the use of Assisted Reproduction techniques, such as in vitro fertilization and the problem of the embryo legal status. Using bibliographic, documental and jurisprudential review, this research also presents a case study: the decision from the Inter-American Court of Human Rights on "Artavia Murillo et al. vs. Costa Rica". The analysis goes beyond the sexual and reproductive rights interpretation in this case, including the jurisdictional dialogues theory to demonstrate how its arguments can improve the debate in the Brazilian scenery, shedding some light in the internal provisions over these rights.
\end{abstract}

Keywords: Reproductive rights; abortion; human rights; judicial dialogues

\section{Referências}

AVILA, Ana Paula Oliveira; SOUZA, Paula Machado Vilela de. Contexto da Discriminação Feminina no Brasil e Legitimação das Medidas Afirmativas de Gênero. Revista Quaestio Juris vol. 10, Rio de Janeiro, 2017, pp. 1610-1632.

BARChifontaine, C. D. P. D. Bioética no início da vida. Rev. Pistis Prax., Teol. Pastor., Curitiba, v. 2 n.1, p. 41-55, jan./jun. 2010.

BARROSO, L. R. Curso de direito constitucional contemporâneo: os conceitos fundamentais e a construção do novo modelo. 3. ed. São Paulo: Saraiva, 2011. 505 p.

BEATTY, D. M. A essência do Estado de direito. São Paulo: WMF Martins Fontes, 2014. 349 p. BRASIL. Código Penal brasileiro. Decreto-lei n. 2848 de 7 de dezembro de 1940: Brasília, 1940. disponível em. Acesso em 5 nov. de 2017.

Lei n. 9.263 de 12 de janeiro de 1996. Brasília: Lei de planejamento familiar, 1996. Disponível em. Acesso em 5 de nov. de 2017.

Decreto Legislativo $n^{\circ} 186$ - Aprova o texto da Convenção sobre os Direitos das Pessoas com Deficiência e de seu Protocolo Facultativo, Brasília, 9 Julho 2008. Disponivel em: $<$ http://www.planalto.gov.br/ccivil_03/Constituicao/Congresso/DLG/DLG-186-2008.htm>.

Acesso em: 4 novembro 2017. assinados em Nova Iorque, em 30 de março de 2007.

. Constituição da República Federativa do Brasil promulgada em 5/10/1988. 46. ed. São Paulo: Saraiva, 2012.

Ministério da Saúde. Secretaria de Atenção à Saúde. Departamento de Atenção Básica. Saúde sexual e saúde reprodutiva / Ministério da Saúde, Secretaria de Atenção à Saúde, Departamento de Atenção Básica, Brasília, n. 1, p. 302, 2013.

CASTALDI, L. D. J.; RAMOS-KURI, M. Artavia Murillo vs. Costa Rica: Análisis crítico a la sentencia de la Corte Interamericana de Derechos Humanos en el fallo sobre fertilización in vitro. 1. ed. Santiago Del Queréteno: CISAV, 2016. 276 p.

CHIA, E. A.; CONTRERAS, P. Análisis de La Sentencia Artavia Murillo y Otros (Fecundación in vitro) vs. Costa Rica de La Corte Interamericana de Derechos Humanos. Estudios constitucionales, Santiago, v. 12, n.1, p. 567-588, julho/ setembro 2014. ISSN 0718-5200. Acesso em 08 out. 2017. COMPARATO, F. K. A afirmação histórica dos direitos humanos. 11. ed. São Paulo: Saraiva, 2017. $619 \mathrm{p}$.

FREITAS, F. et al. Rotinas em Obstetrícia. 6. ed. Porto Alegre: Artmed, 2011. 904 p.

GIDDENS, A. As consequências da modernidade. São Paulo: Unesp, 1991. 193 p.

HABERMAS, J. O futuro da Natureza Humana. São Paulo: WMF Martins Fontes, 2010. 159 p. 
comissão especial para avaliação sobre o aborto alegando "usurpação de prerrogativas" em resposta a voto do Min. Luís Roberto Barroso, do STF, para descriminalização do aborto (HC 124306, julgado na $1^{\text {a }}$ Turma em 29/11/2016).

Este é somente um pequeno apanhado do que o parlamento brasileiro tem feito no Congresso Nacional a respeito dos direitos sexuais e reprodutivos, numa perigosa mistura entre política e religião que revela um perturbador e progressivo afastamento do Estado laico, além do franco retrocesso nas conquistas dos direitos das mulheres no que tange à sexualidade e à reprodução, que mal foram reconhecidas e já correm o risco de perecer. Possivelmente, poucas práticas expressam melhor a reprodução dos padrões históricos de desigualdade, exclusão e preterição baseados em gênero que se apresentam no contexto brasileiro. Essas propostas legislativas no Congresso Nacional são o próprio "modus operandi" da discriminação social da mulher, sobretudo num ambiente em que o homem branco detém a hegemonia no legislativo federal. Nesse sentido, Ávila e Souza observam que

\begin{abstract}
o debate sobre as desigualdades de gênero convivem com valores culturais e regras sociais que têm como base um referencial masculino e branco, o que explica em certa medida o preconceito ainda existente contra a mulher e contra a manifestação de sua autonomia. $(2017$, p. 1611)
\end{abstract}

LEE, S. J. et al. Fetal Pain: a systematic multidisciplinary review of the evidence. JAMA, v. $294 \mathrm{n}$. 8, p. 947-954, 24 August 2005. ISSN doi 10.1001.

LEFEVRE, F.; LEFEVRE, A. M. C. O corpo e seus senhores: homem, mercado e ciência: sujeitos em disputa pela posse do corpo e da mente humana. Rio de Janeiro: Vieira \& Lent, 2009. 96 p.

MUTO, E.; NARLOCH, L. Quando a vida começa? Revista SuperInteressante on line, 31 outubro 2005. Disponível em: $<$ https://super.abril.com.br/ciencia/vida-o-primeiro-instante/\#>. Acesso em 13/10/2017.

NATIONS, U. A/CONF. 171/13 Report of the ICPD 94/10/18. THE INTERNATIONAL CONFERENCE ON POPULATION AND DEVELOPMENT. Cairo: [s.n.]. 1994.

PIOVESAN, F. Sistema Interamericano de Direitos Humanos: impacto transformador, diálogos jurisdicionais e os desafios da reforma. RECHTD Revista de Estudos Constitucionais, Hermenêutica e Teoria do Direito, São Leopoldo, v. 6 n. 02, p. 142-154, 2014. Disponível em:< http://revistas.unisinos.br/index.php/RECHTD/article/view/rechtd.2014.62.03/4299>. Acesso em 29 set. 2017.

., F. Temas de direitos humanos. 10 rev. ampl. e atual. ed. São Paulo: Saraiva, 2017. 696 p.

PIOVESAN, F.; PIROTTA, W. R. B. A proteção dos direitos reprodutivos no Direito Internacional e no Direito Interno. In: PIOVESAN, F. Temas de Direitos Humanos. 10 rev. ampl. e atual. ed. São Paulo: Saraiva, 2017. Cap. 19, p. 447-477.

WIDER, R. Reprodução Assistida: aspectos do biodireito e da bioética. Rio de Janeiro: Lumen Juris, 2007. 156 p.

ZINNY, G. M. S. El embrión como paciente. In: CAYUELA CAYUELA, A., et al. Ética, bioética y desarrollo: El hombre como ser dependiente. Granada: Comares, 2004. p. 91-103. Granada: Comares, 2004. 202 p. 
Em particular quanto à participação das mulheres na arena política, registram que "o dado quantitativo é devastador quando se observa a taxa de a ocupação feminina nos parlamentos mundiais". Segundo pesquisa consultada pelas autoras, o Brasil, com menos de $9 \%$ de ocupação das cadeiras parlamentares por mulheres, está entre os piores colocados no ranking de ocupação feminina nos parlamentos, atrás de 154 países em um total de 187 nações pesquisadas (AVILA e SOUZA, 2017, p. 1626). O mais recente pleito eleitoral, com legislatura iniciando em 2019, elevou para $15 \%$ este patamar, mas mesmo assim não há como garantir, com tamanha desproporção em representatividade, o atendimento das demandas sociais das mulheres, que compõem a demografia brasileira em patamar muito superior $-51,4 \%$ da população ${ }^{31}$ (BRASIL, 2010). Não se pode esquecer que são os corpos e os direitos das mulheres os primeiros a serem sacrificados quando padrões masculinos (em alguns casos mais exacerbados, a própria misoginia) típicos das religiões encontram eco no seio do comando do poder estatal. Por isso, é incumbência do Estado de Direito aliar todos os mecanismos criados para sua autopreservação e ao esforço da ordem interna em articulação com a ordem internacional de direitos humanos para impedir o retrocesso nesses direitos.

\section{Considerações finais}

Esse estudo se propôs a descrever o sistema de proteção aos direitos sexuais e reprodutivos como direitos humanos e fundamentais, previstos em documentos internacionais e no ordenamento jurídico interno. Com a modernidade, viu-se o surgimento e a proliferação de Centros médicos de reprodução assistida no mundo, em resposta ao desenvolvimento tecnológico e científico, suprindo o aumento da demanda por reivindicação de direitos reprodutivos, que por um lado encontra mulheres que já não querem a maternidade compulsória, buscando a contracepção ou mesmo a possibilidade do aborto para gestações indesejadas, mas também, frente à diminuição global da fertilidade e o retardamento da idade para iniciar a constituição de família, buscam tratamentos que as auxiliem a ter filhos.

Descreveram-se alguns dos marcos legais internacionais que corroboram os direitos reprodutivos e sexuais, bem como as principais normas constitucionais e infraconstitucionais do ordenamento jurídico brasileiro. Noutro tópico, em contraponto com os direitos reprodutivos, analisaram-se as controvérsias sobre o status do embrião, as teorias sobre o marco de início da vida humana, algumas das consequências advindas da tecnologia científica e os aspectos bioéticos. Demonstrou-se como essa polêmica pode acabar tendo consequências muito controvertidas, na medida em que a consideração de uma vida em potência, a do nascituro, como um valor absoluto 
em qualquer grau de desenvolvimento que se encontre, possa ser considerada mais preciosa ou até superior à vida, ao corpo e à personalidade da mulher em sua plenitude, implicando em proibições da fertilização assistida e do aborto, e invariavelmente em prejuízo dos direitos sexuais e reprodutivos da mulher, sua integridade física e mental, liberdade e dignidade.

Após, apresentou-se o Caso Artavia Murillo e outros versus Costa Rica que enfrentou na prática as controvérsias apresentadas no desenvolvimento dos capítulos iniciais, mostrando as técnicas de interpretação utilizadas pela Corte no desenvolvimento argumentativo daquele julgamento, principalmente do voto majoritário que deu provimento aos peticionários prejudicados no seu direito reprodutivo de ter filhos. Ressaltou-se que a argumentação da sentença da CIDH foi construída por meio dos diálogos jurisdicionais dos sistemas multinível regionais e global, firmando a orientação de que a proibição da FIV vulnerava a integridade pessoal, a liberdade, a vida privada e o direito à família dos peticionários, e condenando o Estado a modificar a legislação proibitiva e que implementasse as técnicas nos seus serviços de saúde.

Em que pese a sentença estudada tenha sido em 2012, o follow up no site da CIDH demonstrou que até 2016 a Costa Rica, salvo o pagamento das indenizações, ainda não tinha implementado as decisões tomadas pela Corte, e em 2016 um novo grupo de pacientes apresentou nova queixa à Comissão IADH contra Costa Rica. Contudo, recentemente, em 8 de março de 2017, constata-se em reportagens na mídia costa-riquenha que ocorreu o nascimento do primeiro bebê por FIV após a sentença que impôs implementação da técnica no país.

A grande importância desta decisão está em ter fornecido alguns tópicos argumentativos que podem servir de referência no reconhecimento e aprimoramento dos direitos sexuais e reprodutivos nas ordens internas, sobretudo no Brasil, onde muitas questões conexas foram judicializadas perante o STF e seguem em pleno debate. Nesse sentido, percebeu-se que a vida humana em estágio embrionário não foi considerada na decisão da Corte como pessoa humana na sua totalidade. Tomada como "vida em potência", não pode ser avaliada em termos de imposição de tudo ou nada, pressupondo uma gradação de proteção que, no caso concreto, recebeu um peso inferior em relação à vida da mulher que alberga esta vida em potência. Além disso, ao interpretar o art. 4.1 da Convenção Interamericana dos Direitos Humanos, assentou que a expressão "em geral" assume um caráter relativo e de incremento gradual, a ser empregado de acordo com o desenvolvimento do nascituro.

Considerando a elevada carga moral em torno do tema, esta forma de interpretar a questão se harmoniza, inclusive, com os diversos ordenamentos que admitem a realização de aborto sem qualquer pretexto específico até a $12^{\mathrm{a}}$ ou $16^{\mathrm{a}}$ semana de gestação, tal como é admitido em muitos estados norte-americanos e na maior parte dos países da União Europeia, numa evidente manifestação de precedência da liberdade e autonomia da mulher naqueles ordenamentos jurídicos 
internos. Por ter o Brasil aderido à jurisdição da CIDH, o diálogo entre as jurisdições CIDH-STF seria profícuo neste momento em que o Supremo, basicamente, decidirá se punir a mulher pela prática de aborto realiza de modo ótimo os direitos de liberdade e dignidade assegurados às mulheres pela Constituição.

Isso tudo torna desolador, para dizer o mínimo, o panorama da produção legislativa que tramita no parlamento brasileiro, onde as mulheres contam com inexpressiva representatividade, considerando que apenas $9 \%$ dos cargos eletivos são por elas ocupados. Os projetos analisados tomam a direção diametralmente oposta ao desenvolvimento e construção legal que vem sendo operada no sistema internacional de proteção aos direitos humanos sexuais e reprodutivos. Daí a importância do presente estudo para apontar as inconsistências e oferecer argumentos jurídicos e precedentes oriundos de um processo global de diálogos jurisdicionais, que aprimorem as melhores soluções e um enfrentamento mais maduro dos problemas e dúvidas que são comuns à humanidade em geral e às mulheres em particular.

Trabalho recebido em 20 de janeiro de 2019

Aceito em 14 de fevereiro de 2019 